\title{
Permasalahan Subkontrak Pada Pekerjaan Konstruksi di Pemerintah
}

\author{
Ajik Sujoko \\ Fungsional Pengelola Barang/Jasa \\ Fakultas Hukum Undip \\ email : ajik.sujoko80@gmail.com
}

\begin{abstract}
The problem of subcontracting construction work in government is interesting to discuss because in practice construction work is a common thing to do. Therefore it is necessary to understand what subcontracting in construction work in government can be applied, bearing in mind that the current construction work is carried out by a subcontractor network. Three things that need to be considered when implementing subcontracts in government construction work, namely the determination of subcontracts, contract design and subcontracting provisions.
\end{abstract}

Keywords: Subcontracting, Contruction, Goverment

\begin{abstract}
Abstrak
Permasalahan subkontrak pekerjaan konstruksi di pemerintah menarik untuk dibahas, karena dalam praktik pekerjaan konstruksi merupakan hal yang biasa dilakukan. Oleh karena itu perlunya pemahaman subkontrak seperti apa di dalam pekerjaan konstruksi di pemerintah yang dapat diterapkan, mengingat pelaksanaan konstruksi saat ini dilakukan oleh jaringan subkontraktor. Ada empat hal yang perlu diperhatikan ketika menerapkan subkontrak dalam pekerjaan konstruksi pemerintah yaitu penentuan subkontrak, rancangan kontrak dan ketentuan subkontrak.
\end{abstract}

Kata Kunci: subkontrak, Konstruksi, Pengadaan Barang dan Jasa

\section{A. Pendahuluan}

Membicarakan subkontrak memang cukup menarik, terlebih jika ada kasus yang telah muncul. Misalnya kasus mengenai subkontrak pembangunan jalan tol Soreang-Pasirkoja (Soroja). "Puluhan perwakilan dari perusahaan yang menjadi subkontraktor PT Wijaya Karya (Wika) dalam membangun tol Soreang-Pasirkoja (Soroja) berunjuk rasa di depan pintu tol Soreang, Selasa 10 Juli 2018. Unjuk rasa dilakukan dalam rangka menuntut pembayaran pekerjaan mereka. Para pengunjuk rasa ini juga mengancam akan melaporkan ke aparat hukum apabila persoalan ini 
tetap menemui jalan buntu". 1 Ada juga pertanyaan yang cukup menggelitik, seperti pada soal FAKPI 383 di group WhatsApp FAKPI. Penyedia digugat oleh subkonnya. Ternyata subkon tersebut tidak ada dalam kontrak, tidak seijin ppk dan ppk tidak mengetahui dalam pelaksanaan kontrak.

Pertanyaan tersebut memang sangat memungkinkan dan hampir dalam praktik pekerjaan konstruksi di lapangan, kejadiannya serupa dengan pertanyaan tersebut. Subkontrak dalam pengadaan barang/jasa pemerintah memang terbuka dan secara aturan pun membolehkan. ${ }^{2}$ Hal ini bisa dilihat dari ketentuan mengenai peran serta usaha kecil didalam Peraturan Presiden nomor 16 tahun 2018 tentang Pengadaan Barang/Jasa Pemerintah. "Penyedia usaha non-kecil yang melaksanakan pekerjaan dapat melakukan kerja sama usaha dengan usaha kecil dalam bentuk kemitraan, subkontrak, atau bentuk kerja sama lainnya, jika ada usaha kecil yang memiliki kemampuan di bidang yang bersangkutan.” Artinya subkontrak hanya diperbolehkan antara penyedia usaha non kecil dengan usaha kecil.

Dari perspektif penyedia, mensubkon selain membagi resiko, mungkin memiliki pertimbangan lain yaitu efektif dan efisien dalam pelaksanaan pekerjaan konstruksi seperti gambar skema manajemen konstruksi berikut ${ }^{3}$ :

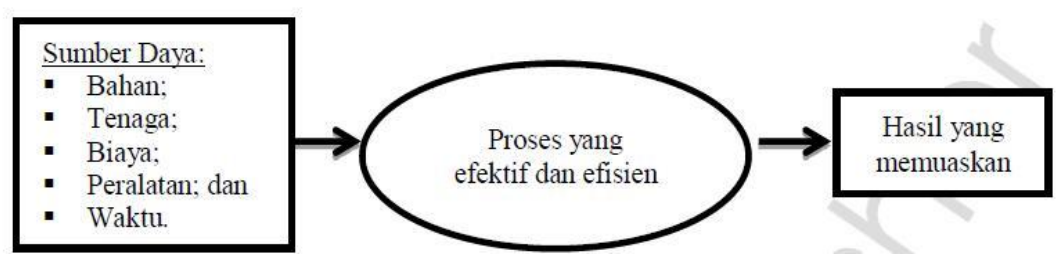

Gambar 1. skema manajemen konstruksi

Dari uraian di atas, melalui tulisan ini untuk mendiskusikan mengenai permasalahan yang ada mengenai subkontrak pada pekerjaan konstruksi di pemerintah.

https://www.pikiran-rakyat.com/bandung-raya/2018/07/10/pembayaran-belum-selesaisubkontraktor-demo-di-gerbang-tol-soroja-427149, di unduh tanggal 28 Januari 2019, jam 11.04

2 Azhar, M., Sujoko, A., \& Suharso, P. (2019). State Financial Losses Due to Corruption in Goods and Service Procurement Systems by the Government. In 2nd International Conference on Indonesian Legal Studies (ICILS 2019) (Vol. 363, pp. 232-236).

3 Hafnidar A. Rani, Manajemen Proyek Konstruksi, Yogyakarta, Deepublish, 2006, hlm. 10. 


\section{B. Pembahasan}

\section{Subkontrak Dalam Dalam Teori Dan Praktik}

Construction projects involve many construction practitioners (owner, consultant, main contractor and subcontractor). ${ }^{4}$ Subkontrak atau istilah lain seperti subkon adalah bentuk/objek dan tidak asing dalam dunia pekerjaan konstruksi. Pelaksana subkon sebagai bentuk/subjek dalam pekerjaan konstruksi biasa disebut subkontraktor (sub contractor), sedang pemberi subkon biasa disebut kontraktor utama (main contractor). Subkontraktor merupakan kontraktor yang menerima pekerjaan pemborongan dari kontraktor lain yang lebih bonafide. ${ }^{5}$

Menurut A.V.Atkinson, $1985,{ }^{6}$ Sub kontraktor dapat dibagi dalam dua kategori yaitu : Subkontraktor nominated dan domestic atau subkontraktor pilihan dan sub kontraktor langganan. Subkontraktor pilihan adalah yang didapatkan dengan pemilihan berdasarkan seleksi penawaran harga yang paling menguntungkan main kontraktor ataupun yang paling baik dan bertanggung jawab terhadap pekerjaan yang akan diberikan kepadanya karena tenaga yang selalu dipakainya adalah tenagatenaga pilihan. Sub kontraktor langganan adalah sub kontraktor yang selalu membantu penyelesaian pekerjaan main kontraktor dan biasa diberi sub pekerjaan dan selalu bertanggung jawab dengan hasil yang memuaskan main kontraktornya.

Pada umumnya kontraktor mengacu pada dokumen tender baik tender yang umum ataupun rinci melakukan penyusunan penawaran harga untuk diberikan ke pemilik proyek. Penawaran harga disusun melalui estimasi dengan menggunakan data historis (database) atau meminta penawaran dari vendorlsupplier atau subkontraktor. ${ }^{7}$ Perusahaan utama (main contractror) yang

4 Borvorn Israngkura Na Ayudhyaa, Masahiko Kunishimab, Risks of Abandonment in Residential Projects Caused by Subcontractors, Procedia Computer Science 121, 2017, hlm. 233.

5 Subkontraktor, https://id.wiktionary.org/wiki/subkontraktor, diunduh tanggal 29 Januari 2019, jam 15.08 .

6 Nurdin Syahril, Kajian Aspek Hukum Sub Kontraktor Bangunan Bawah Dan Drainase Dalam Manajemen Proyek ( Studi kasus pada rencana jembatan Layang Simpang Charitas ), Jurnal Rekayasa Sriwijaya, No. 2 Vol 19, 2010. hlm. 4.

7 PT. PP (Persero)-General Contractor, Buku Referensi untuk Kontraktor Bangunan Gedung dan Sipil, Jakarta, PT. Gramedia Pustaka Utama, hlm. 18 
memenangkan tender diperbolehkan mensubkontrakkan pekerjaan yang sifatnya khusus/spesifik atau harus dilakukan oleh perusahaan kecil (subcontractor), meskipun tanggung jawab utama terletak pada main contractor. Dalam kontrak pelaksanaan pekerjaan, antara main contractor dengan sub contractor dibuat kontrak kerja diantara mereka. ${ }^{8}$ It is common practice for the majority of the work to be subcontracted to subcontractor while main contractor manages a contract (Matthews et al., 1997) ${ }^{9}$.

Menjadi tantangan praktis dan teoritis dalam menerapkan aturan main mengenai subkon dalam pekerjaan konstruksi, terlebih dalam pekerjaan konstruksi yang komplek. Pemahaman dan pengetahuan subkon dari praktis dan teoritis yang didapat dari peraturan dan pelaksanaan mengenai subkon. Perluya pemahaman mengenai subkon karena banyak kegiatan di pelaksanaan konstruksi saat ini dilakukan oleh jaringan subkontraktor. In safety critical industries many activities are currently carried out by subcontractor networks. ${ }^{10}$

Dalam proses tender pekerjaan konstruksi yang dilakukan oleh pemerintah, khusus mengenai subkon idealnya sudah ditentukan sejak tahap perencanaan. Pada umumnya proses tender mencari siapa yang akan menjadi main kontraktor, namun, kriteria subkontraktor yang seperti apa tidak begitu detail disyaratkan. Bahkan bentuk atau suatu keharusan perjanjian kerja antara main kontraktor dengan subkontraktor kurang diperhatikan. Misalnya mengenai jaminan/guarantee atau pemeliharaan yang dikerjakan oleh subkontraktor.

\section{Jenis Subkontrak dan Subkontraktor}

Dilihat dari skema manajemen konstruksi, bisa dilihat input suatu proses pekerjaan konstruksi yang terdiri sumber daya yaitu bahan, tenaga, biaya, peralatan dan waktu. Dari ke lima sumber daya tersebut, apakah dapat dilakukan subkon?

a. Bahan

8 Ajik Sujoko, Outsourcing Jasa Kebersihan di Instansi Pemerintah, Majalah Masalah - Masalah Hukum, Jilid 46 No. 4, Oktober 2017, hlm. 374.

9 Op.Cit. Borvorn.

10 Pia Oedewaldn, Nadezhda Gotcheva, Safety Culture And Subcontractor Network Governance In A Complex Safety Critical Project, journal homepage: www.elsevier.com/locate/ress, hlm. 106. 
Bahan atau material atau komponen bangunan yang digunakan untuk keperluan pekerjaan konstruksi dapat dari pabrikan, rakitan/handmade atau bersumber dari alam. Proses pengadaan bahan atau material oleh main contractor memungkinkan dilakukan oleh sub contractor.

b. Tenaga

Tenaga yang dimaksud adalah tenaga kerja yang melaksanakan pekerjaan konstruksi atau pelaksana kegiatan kontruksi. Tenaga memungkinkan dilakukan subkon dalam pelaksanaan pekerjaan konstruksi. Banyak kontraktor dengan keterbatasan tenaga meminta pada kontraktor lain atau penyedia jasa tenaga untuk mensuplay tenaga sebagai pelaksana kegiatan konstruksi.

c. Biaya

Biaya adalah dana yang digunakan untuk membiayai pelaksanaan pekerjaan konstruksi. Sumber biaya kontraktor bisa diperoleh dari sumber dana kontraktor sendiri atau pihak luar. Pihak luar itu bisa dari lembaga keuangan seperti bank atau asuransi maupun sesama kontraktor, bahkan pinjaman pribadi. Pada umumnya istilah perolehan dana oleh kontraktror dari pihak luar tidak dikenal istilah subkon biaya, tetapi lebih popular dengan sebutan "utang". Jika merujuk pada pendapat Matthews et al., 1997, dimana kontraktor utama mengelola kontrak tidak mustahil secara teori, biaya dapat disubkan kepada pihak lain.

d. Peralatan

Peralatan merupakan alat yang digunakan untuk melaksanakan pekerjaan konstruksi. Penyediaan peralatan dapat disubkon kepada pihak lain seperti kontraktor lain atau pemilik peralatan konstruksi.

e. Waktu

Waktu merupakan batasan penyelesaian pekerjaan dalam konstruksi yang ditentukan. Cukup sulit untuk mendeskripsikan subkon mengenai waktu. Belum ditemukan referensi mengenai subkon mengenai waktu. Namun demikian umumnya waktu mengikuti kegiatan suatu subkon bahan/tenaga/peralatan. Misalnya mensubkon peralatan dengan waktu sekian hari.

Dari kelima sumber daya di atas, mudah ditemukan dalam praktik di lapangan, bahwa pekerjaan subkon sebagai suatu input suatu proses pekerjaan konstruksi terdiri 
dari subkon bahan/tenaga/peralatan atau percampuran dari ketiganya. Lain halnya ketika dalam suatu proses pelaksanaan pekerjaan konstruksi menurut skema manajemen konstruksi agar efisien dan efektif. Subkon dalam tahap proses ini lebih variatif dan sudah menyangkut pekerjaan. Objek atau bentuk subkon yang sering ditemui dalam praktik maupun secara terori adalah pekerjaan dan gabungan pekerjaan dengan bahan/tenaga/peralatan/biaya

\section{Jenis Subkontraktor}

Subkontraktor dibedakan menjadi 2 macam, yaitu : ${ }^{11}$

a. Subkontraktor yang menyediakan pekerja saja, yaitu subkontraktor yang dalam melaksanakan pekerjaan konstruksi hanya menyediakan tenaga kerja dan alat kerja konstruksi (traktor, mesin pancang, dan sebagainya), sedangkan bahan bangunan disediakan oleh perusahaan yang mensubkontrakkan.

b. Subkontraktor yang menyediakan pekerja dan material konstruksi, yaitu subkontraktor yang menerima dan melaksanakan sebagian/seluruh pekerjaan/proyek konstruksi yang disubkontrakkan secara penuh oleh perusahaan kontraktor, artinya penyediaan bahan bangunan dan tenaga kerja seluruhnya adalah tanggung jawab subkontraktor.

Jika melihat setidaknya ada bentuk/objek subkon, secara teori subkontraktor dapat mengikuti dari bentuk subkon tersebut seperti bagan 1 di bawah ini:

\begin{tabular}{|c|c|c|}
\hline No & Bentuk Subkon / (Objek) & Bentuk Subkontraktor (Subjek) \\
\hline 1 & Bahan & Bahan \\
\hline 2 & Tenaga & Tenaga \\
\hline 3 & Biaya & Biaya \\
\hline 4 & Peralatan & Peralatan \\
\hline 5 & Pekerjaan & Pekerjaan \\
\hline 6 & Gabungan bahan/tenaga/peralatan/biaya & Gabungan bahan/tenaga/peralatan/biaya \\
\hline 7 & $\begin{array}{l}\text { Gabungan pekerjaan dengan } \\
\text { bahan/tenaga/peralatan/biaya }\end{array}$ & $\begin{array}{l}\text { Gabungan pekerjaan dengan } \\
\text { bahan/tenaga/peralatan/biaya }\end{array}$ \\
\hline
\end{tabular}

Bagan 1. Bentuk Subkon dan Subkontraktor

\section{Subkontrak dalam teori dan praktik}

11 Pengertian Subkontraktor Pada Proyek, https://projectmedias.blogspot.com/2014/01/ pengertiansubkontraktor-pada-proyek.html, diunduh tanggal 29 Januari 2019, jam 15.09. 
Jika merujuk pada pendapat Matthews et al., 1997, dimana kontraktor utama mengelola kontrak tidak mustahil secara terori biaya dapat disubkan kepada pihak lain. Secara teoritis dapat dibuat skema subkon mengenai biaya seperti bagan 2 berikut :

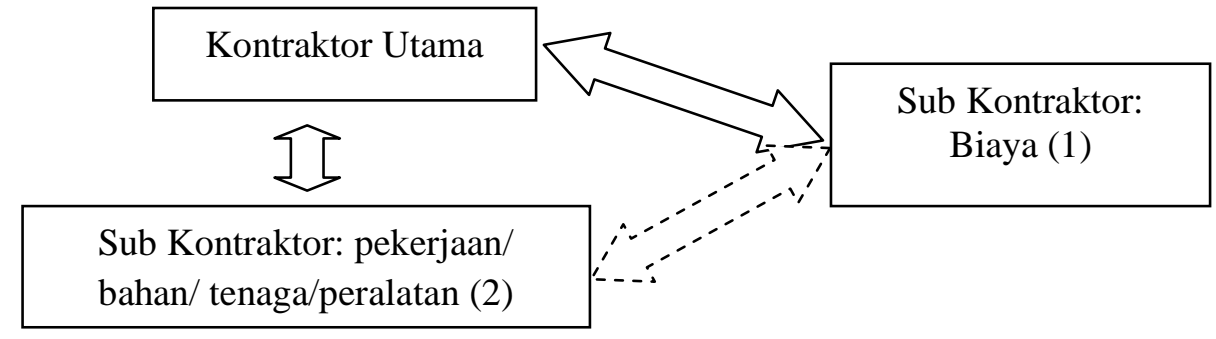

Bagan 2. Skema subkontraktor biaya

Secara teoritis dari bagan 2 mengenai skema subkontraktor biaya dapat diuraikan sebagai berikut:

a. Kontraktor Utama memiliki 2 atau lebih subkontraktor, yang pertama subkontraktor biaya (1) dan yang kedua subkontraktor: pekerjaan/ bahan/ tenaga/peralatan (2)

b. Koordinasi kontraktor utama dengan kedua subkontraktor hubungan timbal balik, karena antara kontraktor utama dengan subkontraktor memiliki hak dan kewajiban. Hubungan kontraktual yang saling menguntungkan antara kontraktor dan subkontraktor, serta supplier akan memberikan "daya beli" yang kuat pada perusahaan. Hal ini berdampak pada penerimaan bahan yang tepat waktu dan segera dengan pelayanan yang lebih baik dan harga yang kompetitif. Ini memungkinkan perusahaan memberikan pelayanan yang lebih baik kepada pemilik proyek berupa waktu pelaksanaan yang lebih cepat, kualitas kerja yang lebih baik dengan harga yang lebih ekonomis. ${ }^{12}$

c. Hubungan subkontraktor (1) dengan subkontraktor (2) bisa timbal balik atau koordinasi. Jika timbal balik tentunya ada hak dan kewajiban di antara keduanya. Jika koordinasi, sekedar kewajiban subkontraktor (1) membayar semua biaya yang ditagihkan dari subkontraktor (2) kepada kontraktor utama melalui dari subkontrakror (1).

Subkontrak dalam praktik dapat dilihat seperti bagan 3 berikut :

12 PT. PP (Persero)-Gene Kontraktor Utama h. 9 


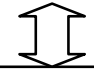

Sub Kontraktor 1

Bagan 3. Skema subkontraktor dalam praktik 1

Subkontrak dalam praktik yang lain dapat dilihat seperti bagan 4 berikut :

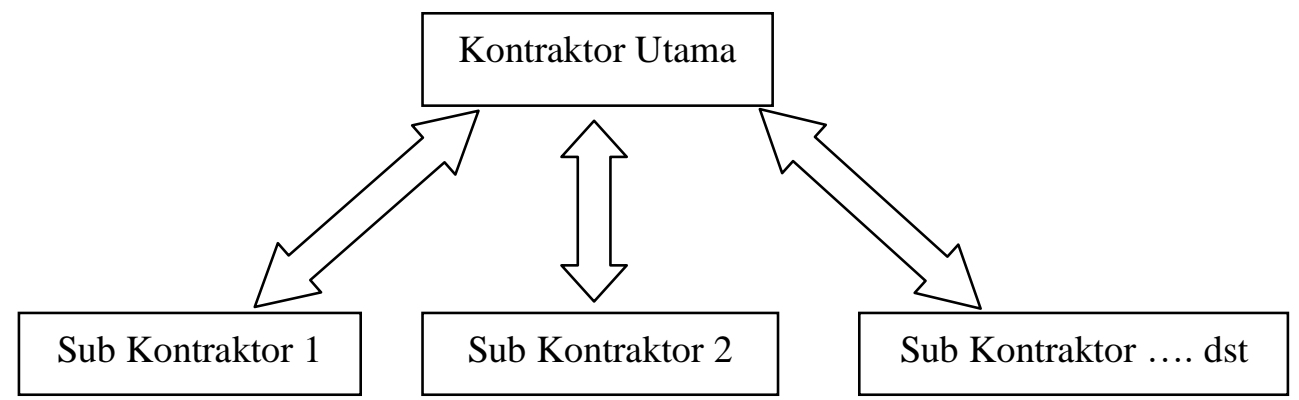

Bagan 4. Skema subkontraktor dalam praktik 2

Subkontrak dalam praktik yang lain dapat dilihat seperti bagan 5 berikut :

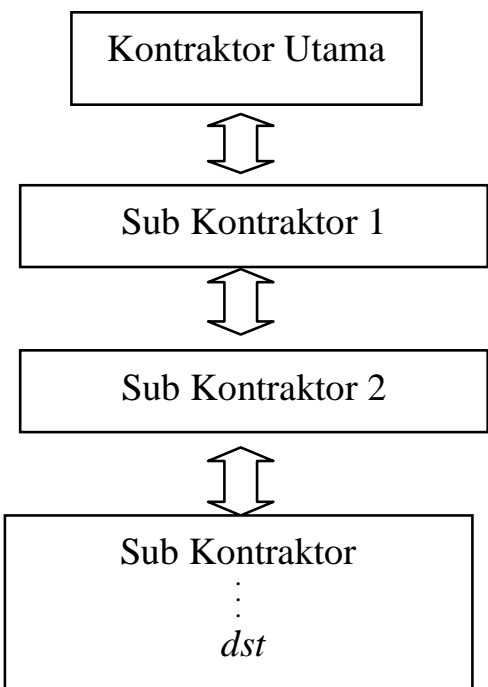

Bagan 5. Skema subkontraktor dalam praktik 3

Dari berbagai varian subkontrak di atas, mungkin bisa ditemui praktik subkontrak yang berbeda. Praktik subkontrak idealnya ada perjanjian/kontrak secara tertulis antara kontraktor utama dengan subkontraktor. Namun praktik pemberian subkon dari kontraktor utama kepada subkontraktor terkadang banyak ditemui secara lisan. Dalam praktiknya pemilihan subkontraktor dilakukan secara penunjukan 
langsung kepada subkontraktor yang sudah terbiasa bekerja sama atau dengan proses lelang.

\section{Hubungan hukum Subkontrak}

Secara terori, hubungan hukum subkontrak antara kontraktor utama dengan subkontraktor ditentukan dalam perjanjian/kontrak kerja/kontrak kerja konstruksi antara kontraktor utama dengan subkontraktor. Ada 2 skema hubungan hukum yang bisa diterapkan mengenai subkontrak terkait dengan pemilik pekerjaan (owner) yaitu

a. Skema peduli (care)

Hubungan hukum antara pemilik pekerjaan (owner) dengan kontraktor utama (main contractor) dengan subkontraktor (sub contractor) bisa dilihat dalam bagan 6 sebagai berikut:

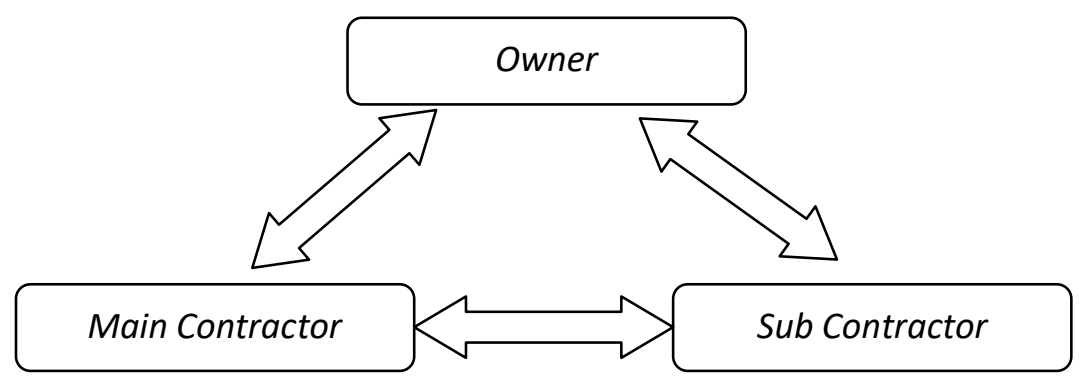

Bagan 6. hubungan hukum subkon skema peduli

Dalam tipe peduli ini, secara kontraktual ada hubungan hukum antara owner dengan main contractor maupun dengan sub contractor, dan main contractor pun memiliki hubungan secara kontraktual dengan sub contractor.

b. Skema tidak peduli (not care)

Hubungan hukum antara pemilik pekerjaan (owner) dengan kontraktor utama (main contractor) dengan subkontraktor (sub contractor) bisa dilihat dalam bagan 7 sebagai berikut:

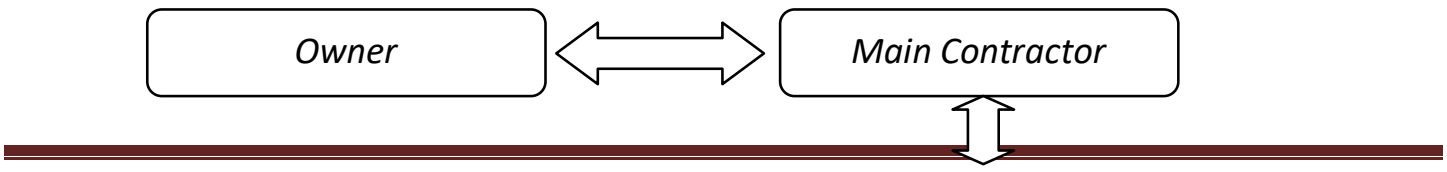




\section{Sub Contractor}

Bagan 7. hubungan hukum subkon skema tidak peduli

Dalam skema tidak peduli ini, secara kontraktual ada hubungan hukum antara owner dengan main contractor, sedangkan antara main contractor dengan sub contractor pun memiliki hubungan secara kontraktual. Dalam skema tidak peduli, owner tidak peduli (not care) dengan sub contractor. Owner hanya melihat hasil pekerjaan dari main contractor, artinya main contractor bertanggung jawab secara kontraktual hasil pekerjaan kepada owner.

Dari kedua skema hubungan hukum subkontrak terdapat kelebihankekurangannya atau perbandingan antara lain seperti bagan 8 berikut :

\begin{tabular}{|c|c|c|}
\hline $\begin{array}{l}\text { Kelebihan- } \\
\text { Kekurangan/ } \\
\text { Perbandingan }\end{array}$ & Skema peduli (care) & $\begin{array}{l}\text { Skema tidak peduli } \\
\text { (not } \text { care })\end{array}$ \\
\hline $\begin{array}{l}\text { Tanggung jawab hasil } \\
\text { pekerjaan akhir kepada } \\
\text { owner }\end{array}$ & $\begin{array}{l}\text { pilihan: } \\
\text { a. main contractor } \\
\text { b. main contractor dan sub contractor } \\
\text { c. sub contractor }\end{array}$ & main contractor \\
\hline Tagihan pembayaran & $\begin{array}{l}\text { Pilihan: } \\
\text { a. melalui main contractor } \\
\text { b. langsung dari sub contractor }\end{array}$ & $\begin{array}{l}\text { melalui main contractor } \\
\text { (dilampiri bukti pembayaran kepada } \\
\text { sub contractor) }\end{array}$ \\
\hline $\begin{array}{l}\text { Pembayaran dari } \\
\text { owner }\end{array}$ & $\begin{array}{l}\text { Pilihan: } \\
\text { a. melalui main contractor } \\
\text { b. langsung kepada sub contractor }\end{array}$ & melalui main contractor \\
\hline $\begin{array}{l}\text { Tanggung jawab masa } \\
\text { pemeliharaan }\end{array}$ & $\begin{array}{l}\text { pilihan: } \\
\text { a. main contractor dan sub contractor } \\
\text { b. sub contractor }\end{array}$ & main contractor \\
\hline $\begin{array}{l}\text { Tanggung jawab } \\
\text { kegagalan bangunan }\end{array}$ & main contractor & main contractor \\
\hline $\begin{array}{l}\text { Koordinasi pekerjaan } \\
\text { dengan owner }\end{array}$ & $\begin{array}{l}\text { main contractor dan sub contractor } \\
\text { (kurang efektif) }\end{array}$ & main contractor (lebih efektif) \\
\hline
\end{tabular}

Bagan 8. Kelebihan-kekurangan/perbandingan skema hubungan hukum subkon 


\section{Subkontrak Dalam Pekerjaan Konstruksi Di Pemerintah}

Kebijakan pemerintah di dalam pengadaan barang/jasa pemerintah juga menyinggung peran serta usaha kecil. Pasal 65 ayat (6) Perpres nomor 16 tahun 2018 disebutkan bahwa penyedia usaha non-kecil yang melaksanakan pekerjaan dapat melakukan kerja sama usaha dengan usaha kecil dalam bentuk kemitraan, subkontrak, atau bentuk kerja sama lainnya, jika ada usaha kecil yang memiliki kemampuan di bidang yang bersangkutan. Pasal 63 ayat (3) Perpres nomor 16 tahun 2018 disebutkan bahwa badan usaha asing yang mengikuti Tender/ Seleksi Internasional sebagaimana dimaksud pada ayat (1), harus melakukan kerja sama usaha dengan badan usaha nasional dalam bentuk konsorsium, subkontrak, atau bentuk kerja sama lainnya.

Tender/ Seleksi Internasional dapat dilaksanakan untuk:

a. Pengadaan Pekerjaan Konstruksi dengan nilai paling sedikit di atas Rp1.000.000.000.000,00 (satu triliun rupiah);

b. Pengadaan Barang/Jasa Lainnya dengan nilai paling sedikit di atas Rp50.000.000.000,00 (lima puluh miliar rupiah);

c. Pengadaan Jasa Konsultansi dengan nilai paling sedikit di atas Rp25.000.000.000,00 (dua puluh lima miliar rupiah); atau

d. Pengadaan Barang/Jasa yang dibiayai oleh Lembaga Penjamin Kredit Ekspor atau Kreditor Swasta Asing

Subkontrak menurut Peraturan Lembaga Kebijakan Pengadaan Barang/Jasa Pemerintah Nomor 10 Tahun 2018 Tentang Pedoman Pelaksanaan Tender/Seleksi Internasional yaitu bentuk kerjasama usaha antara 2 (dua) perusahaan atau lebih (yang terdiri atas Pelaku Usaha Nasional dan Pelaku Usaha Asing), dimana Pelaku Usaha utama bertanggung jawab penuh terhadap pekerjaan, mengkoordinasikan pekerjaan dengan subkontraktor, dan menandatangani Kontrak dengan PPK. Subkontraktor melaksanakan bagian dari Kontrak yang ditugaskan kepadanya berdasarkan Kontrak dari Pelaku Usaha utama. Subkontraktor adalah pihak ketiga yang dilibatkan oleh Pelaku Usaha utama dalam suatu pekerjaan untuk melaksanakan pekerjaan-pekerjaan tertentu. 
Melihat dari ketentuan subkontrak menurut Perpres nomor 16 tahun 2018, pada prinsipnya subkontrak dapat dilakukan ketika kontraktor utama adalah :

a. Penyedia usaha non-kecil

b. badan usaha asing

Perpres nomor 16 tahun 2018 juga menyinggung syarat pembayaran prestasi pekerjaan berkaitan dengan subkontraktor. Pasal 53 ayat (3) Perpres nomor 16 tahun 2018 disebutkan bahwa dalam hal penyedia menyerahkan sebagian pekerjaan kepada subkontraktor, permintaan pembayaran harus dilengkapi bukti pembayaran kepada subkontraktor sesuai dengan realisasi pekerjaannya. Di dalam Peraturan Lembaga Kebijakan Pengadaan Barang/Jasa Pemerintah nomor 9 Tahun 2018 tentang Pedoman Pelaksanaan Pengadaan Barang/Jasa melalui Penyedia juga dijelaskan untuk pekerjaan yang di subkontrakkan, permintaan pembayaran dilengkapi bukti pembayaran kepada subpenyedia/subkontraktor sesuai dengan kemajuan hasil pekerjaan.

Dari uraian subkontrak menurut Perpres nomor 16 tahun 2018 disimpulkan bahwa bentuk subkotrak dari kotraktor utama kepada subkontraktor sebatas dalam bentuk subkon pekerjaan. Isitilah kontraktor utama menurut menurut Perpres nomor 16 tahun 2018 adalah penyedia/pelaku usaha utama sedangkan subkontraktor istilahnya sama.

\section{Subkontrak menurut Undang-Undang Nomor 2 Tahun 2017 Tentang Jasa} Konstruksi

Di dalam Undang-Undang Nomor 2 Tahun 2017 tentang Jasa Konstruksi tidak dikenal istilah subkontraktor, melainkan Subpenyedia jasa adalah pemberi layanan jasa konstruksi kepada penyedia jasa. Penyedia Jasa adalah pemberi layanan Jasa Konstruksi. Pasal 52 Undang-Undang Nomor 2 Tahun 2017 dijelakaskan penyedia jasa dan subpenyedia jasa dalam penyelenggaraan jasa konstruksi harus diantaranya sesuai dengan perjanjian dalam kontrak.

Hubungan kerja antara Pengguna Jasa dan Penyedia Jasa harus dituangkan dalam kontrak kerja konstruksi. Ketentuan mengenai kontrak kerja konstruksi berlaku juga dalam kontrak kerja konstruksi antara penyedia jasa dan subpenyedia jasa. Pasal 53 Undang-Undang Nomor 2 Tahun 2017 dijelaskan dalam 
penyelenggaraan jasa konstruksi, pekerjaan utama hanya dapat diberikan kepada subpenyedia jasa yang bersifat spesialis antara lain:

a. instalasi;

b. konstruksi khusus;

c. konstruksi prapabrikasi;

d. penyelesaian bangunan; dan

e. penyewaan peralatan.

Pemberian pekerjaan utama kepada subpenyedia jasa yang bersifat spesialis harus mendapat persetujuan pengguna jasa.

Dalam lampiran Peraturan Menteri Pekerjaan Umum dan Perumahan Rakyat Nomor: 31/PRT/M/2015 tentang Perubahan Ketiga Peraturan Menteri Pekerjaan Umum Nomor 07/PRT/M/2011 tentang Standar Dan Pedoman Pengadaan Pekerjaan Konstruksi dan Jasa Konsultansi, pekerjaan utama adalah jenis pekerjaan yang secara langsung menunjang terwujudnya dan berfungsinya suatu konstruksi sesuai peruntukannya yang ditetapkan sebagaimana tercantum dalam Dokumen Pengadaan.

Dalam penyelenggaraan jasa konstruksi, penyedia jasa dengan kualifikasi menengah dan/atau besar mengutamakan untuk memberikan pekerjaan penunjang kepada subpenyedia jasa dengan kualifikasi kecil. Di dalam lampiran Peraturan Menteri Pekerjaan Umum dan Perumahan Rakyat Nomor: 31/PRT/M/2015 pekerjaan penunjang/sementara misalnya:

(1) Pembuatan saluran pengelak (diversion channel);

(2) Pengeringan tempat pekerjaan (dewatering/unwatering) skala besar;

(3) Pembuatan konstruksi pengaman (protection construction);

(4) Pengaturan lalu lintas (traffic management) pekerjaan skala besar; atau

(5) Jalan pengalihan/jembatan sementara

Penyedia jasa dan subpenyedia jasa wajib memenuhi hak dan kewajiban sebagaimana tercantum dalam kontrak kerja konstruksi. Dalam pasal 48 huruf b Undang-Undang Nomor 2 Tahun 2017 dijelaskan kontrak kerja konstruksi untuk kegiatan pelaksanaan layanan jasa konstruksi, dapat memuat ketentuan tentang subpenyedia jasa serta pemasok bahan, komponen bangunan, dan/atau peralatan yang harus memenuhi standar yang berlaku. 
Di dalam lampiran Peraturan Menteri Pekerjaan Umum dan Perumahan Rakyat Nomor: 31/PRT/M/2015 dijelaskan, pekerjaan utama adalah jenis pekerjaan yang secara langsung menunjang terwujudnya dan berfungsinya suatu konstruksi sesuai peruntukannya yang ditetapkan sebagaimana tercantum dalam dokumen pengadaan. Bagian pekerjaan yang disubkontrakan adalah bagian pekerjaan bukan pekerjaan utama, atau pekerjaan spesialis yang ditetapkan sebagaimana tercantum dalam dokumen pemilihan. Seiring berlakunya Permen PUPR No.07/PRT/M/2019, tentang Standar dan Pedoman Pengadaan Jasa Konstruksi Melalui Penyedia, penentuan subkontrak ditentukan dalam dokumen pemilihan.

Dalam hal penyelenggaraan jasa konstruksi menggunakan anggaran pendapatan dan belanja daerah (APBD) serta memenuhi kriteria berisiko kecil sampai dengan sedang, berteknologi sederhana sampai dengan madya, dan berbiaya kecil sampai dengan sedang, Pemerintah Daerah provinsi dapat membuat kebijakan khusus $^{13}$. Kebijakan khusus di antaranya penggunaan subpenyedia jasa daerah. Dalam penyelenggaraan jasa konstruksi, penyedia jasa dan/atau subpenyedia jasa wajib menyerahkan hasil pekerjaannya secara tepat biaya, tepat mutu, dan tepat waktu sebagaimana tercantum dalam kontrak kerja konstruksi. Penyedia jasa dan/atau subpenyedia jasa yang tidak menyerahkan hasil pekerjaannya secara tepat biaya, tepat mutu, dan/atau tepat waktu dapat dikenai ganti kerugian sesuai dengan kesepakatan dalam kontrak kerja konstruksi. Pengguna jasa bertanggung jawab atas biaya jasa konstruksi sesuai dengan kesepakatan dalam kontrak kerja konstruksi.

Dari uraian Undang-Undang Nomor 2 Tahun 2017 tentang Jasa Konstruksi, bentuk subkontrak antara kontraktor utama dengan subkontraktor adalah

a. pekerjaan utama yang bersifat spesialis

b. pekerjaan penunjang

c. pemasok bahan, komponen bangunan, dan/atau peralatan

Isitilah kontraktor utama menurut Undang-Undang Nomor 2 Tahun 2017 tentang Jasa Konstruksi penyedia jasa sedangkan subkontraktor adalah subpenyedia jasa.

13 Azhar, M., \& Suhartoyo, S. (2015). Aspek Hukum Kebijakan Geothermal Di Indonesia. Law Reform, 11(1), 123-138. https://doi.org/10.14710/lr.v11i1.15761 


\section{Subkontrak menurut Federation Internationale des Ingenieurs-Conseils (FIDIC)}

Di dalam buku mengenai Persyaratan Kontrak Untuk Pelaksanaan Konstruksi MDB Harmonised Edition, yang diterjemahkan ke dalam Bahasa (dengan lisensi dari FIDIC, 10 November 2007) Indonesia oleh Sarwono Hardjomuljadi dkk, subkontraktor berarti semua orang yang disebutkan di dalam kontrak sebagai subkontraktor, atau siapa saja yang ditunjuk sebagai subkontraktor, untuk suatu bagian dari pekerjaan; dan pengganti sah dari jabatan orang-orang tersebut. Kontraktor berarti orang (orang-orang) yangdisebutkan sebagai kontraktor dalam Surat Penawaran yang diterima oleh Pengguna Jasa dan pengganti sah dalam jabatan dari orang (orang-orang) tersebut.

Kontraktor tidak boleh mensubkontrakkan seluruh pekerjaan. Kontraktor harus bertanggungjawab atas tindakan dan kegagalan subkontraktor, agen atau karyawan, sebagaimana tindakan atau kegagalan Kontraktor. Kecuali apabila ditentukan lain dalam persyaratan khusus, diantaranya kontraktor tidak perlu memperoleh persetujuan untuk pemasok tunggal bahan, atau untuk suatu subkontrak yang nama subkontraktornya tercantum dalam kontrak (sub kontraktor yang dinominasikan).

Apabila kewajiban subkontraktor melampaui masa berlakunya masa pemberitahuan cacat mutu dan enjinir, sebelum tanggal tersebut, menginstruksikan kontraktor untuk bertanggungjawab atas kewajiban subkontraktor bagi kepentingan pengguna jasa, maka kontraktor harus melaksanakannya. Kecuali apabila ditentukan lain dalam penugasan tersebut, kontraktor tidak bertanggungjawab kepada pengguna jasa atas pekerjaan yang dilaksanakan subkontraktor setelah penugasan tersebut berlaku.

Sebelum menerbitkan Sertifikat Pembayaran termasuk jumlah yang harus dibayarkan kepada Subkontraktor yang dinominasikan, Enjinir dapat meminta kepada Kontraktor untuk menyampaikan bukti-bukti bahwa Subkontraktor telah menerima jumlah yang menjadi haknya sesuai dengan Sertifikat Pembayaran sebelumnya, dikurangi dengan pengurangan untuk retention atau sebaliknya.Kecuali jika Kontraktor:

a) Menyampaikan bukti yang dapat diterima kepada Enjinir, atau 
b) (i) menjelaskan secara tertulis kepada Enjinir bahwa Kontraktor memang beralasan menahan dan tidak membayarkan jumlah tersebut, dan

(ii) menyampaikan kepada Enjinir bukti-bukti yang dapat diterima bahwa Subkontraktor yang dinominasikan telah diberitahukan apa yang berhak dilakukan Kontraktor.

Selanjutnya Pengguna Jasa dapat (karena kehendaknya sendiri) membayar secara langsung kepada Subkontraktor yang dinominasikan, sebagian atau seluruh jumlah yang sebelumnya telah disahkan (dikurangi potongan-potongan) merupakan hak Subkontraktor yang dinominasikan dan untuk mana Kontraktor telah gagal menyampaikan bukti-bukti sebagaimana dinyatakan dalam subparagraph (a) atau (b) diatas. Kontraktor selanjutnya harus membayar kembali, kepada Pengguna Jasa, jumlah yang dibayarkan oleh Pengguna Jasa langsung kepada Subkontraktior yang dinominasikan.

Dari uraian ketentuan subkontrak menurut FIDIC di atas, bentuk subkontrak antara kontraktor utama dengan subkontraktor adalah

a. pekerjaan

b. suatu subkontrak, apabila ditentukan lain dalam persyaratan khusus

Isitilah kontraktor utama disebut kontraktor sedangkan subkontraktor istilahnya sama.

\section{Permasalahan Subkontrak Dalam Pekerjaan Konstruksi Di Pemerintah}

\subsection{Subkontrak yang diperbolehkan}

Dari ketentuan normatif mengenai subkontrak, dengan merujuk pada peraturan pengadaan dan konstruksi yang ada, bisa dilihat dalam bagan 9 antara lain:

\begin{tabular}{|l|l|ll|}
\hline Peraturan & \multicolumn{2}{l|}{ Bentuk Subkontrak } \\
\hline Perpres No. 16 Tahun & pekerjaan & $\bullet$ & pekerjaan-pekerjaan tertentu \\
2018 & & $\bullet$ & sebagian pekerjaan \\
\hline Undang-Undang & a. $\quad$ pekerjaan utama & $\bullet$ & instalasi; \\
Nomor 2 Tahun 2017 & yang bersifat & - & konstruksi khusus; \\
& spesialis & $\bullet$ & konstruksi prapabrikasi; \\
& & $\bullet$ & penyelesaian bangunan; dan \\
\hline
\end{tabular}




\begin{tabular}{|c|c|c|}
\hline & & - penyewaan peralatan. \\
\hline & $\begin{array}{l}\text { b. pekerjaan } \\
\text { penunjang }\end{array}$ & $\begin{array}{ll}\text { - } & \text { Pembuatan saluran pengelak } \\
\text { - } & \text { Pengeringan tempat pekerjaan skala } \\
\text { besar } \\
\text { - } \\
\text { - Pembuatan konstruksi pengaman } \\
\text { Pengaturan lalu lintas pekerjaan skala } \\
\text { - Jalan pengalihan/jembatan sementara } \\
\text { - }\end{array}$ \\
\hline & $\begin{array}{l}\text { c. bahan, komponen } \\
\text { bangunan, }\end{array}$ & Ditentukan dalam kontrak \\
\hline & d. peralatan & Ditentukan dalam kontrak \\
\hline FIDIC & a. pekerjaan & sebagian pekerjaan \\
\hline & b. suatu subkontrak & $\begin{array}{l}\text { apabila ditentukan lain dalam persyaratan } \\
\text { khusus }\end{array}$ \\
\hline
\end{tabular}

Bagan 9. Subkontrak yang diperbolehkan

\subsection{Subkontrak yang tidak diperbolehkan}

Dari ketentuan normatif mengenai subkontrak, dengan merujuk pada peraturan pengadaan dan konstruksi yang ada, bisa dilihat dalam bagan 10 antara lain:

\begin{tabular}{|c|c|c|}
\hline Peraturan & \multicolumn{2}{|l|}{ Bentuk Subkontrak } \\
\hline $\begin{array}{l}\text { Perpres No. } 16 \text { Tahun } \\
2018\end{array}$ & pekerjaan & Semua pekerjaan \\
\hline \multirow[t]{3}{*}{$\begin{array}{l}\text { Undang-Undang } \\
\text { Nomor } 2 \text { Tahun } 2017\end{array}$} & $\begin{array}{ll}\text { a. } & \text { pekerjaan utama } \\
& \text { yang tidak } \\
& \text { bersifat spesialis }\end{array}$ & 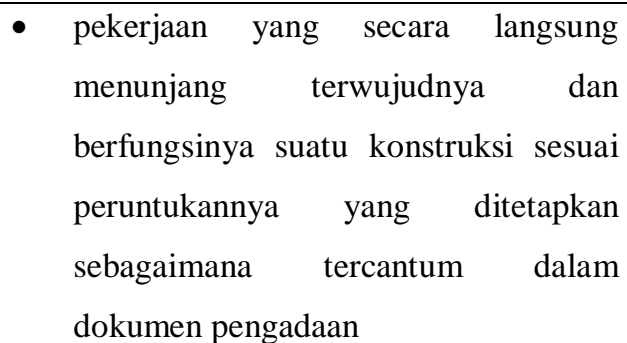 \\
\hline & b. biaya & \\
\hline & c. tenaga & \\
\hline \multirow[t]{2}{*}{ FIDIC } & a. pekerjaan & Semua pekerjaan \\
\hline & b. suatu subkontrak & $\begin{array}{l}\text { tidak ditentukan lain dalam persyaratan } \\
\text { khusus }\end{array}$ \\
\hline
\end{tabular}

Bagan 10. Subkontrak yang tidak diperbolehkan 


\subsection{Permasalahan subkontrak dalam pekerjaan kontruksi}

Secara garis besar permasalahan subkontrak terbagi menjadi 2 yaitu :

a. Ditentukan dalam kontrak

b. Tidak ditentukan dalam kontrak, namun dilakukan subkontrak

Dari kedua permasalahan tersebut dalam praktiknya menuai masalah baik dalam pelaksanaan pekerjaan maupun sampai masa pemeliharaan. Variasi masalah dari kedua permasalahan subkontrak antara lain seperti bagan 11 berikut:

\begin{tabular}{|c|c|c|c|c|}
\hline $\begin{array}{l}\text { Permasalahan } \\
\text { subkontrak }\end{array}$ & $\begin{array}{l}\text { Pelaksanaan } \\
\text { Pekerjaan }\end{array}$ & $\begin{array}{c}\text { Pekerjaan } \\
\text { tidak selesai }\end{array}$ & $\begin{array}{c}\text { Pekerjaan } \\
\text { selesai }\end{array}$ & $\begin{array}{c}\text { Masa } \\
\text { Pemeliharaan }\end{array}$ \\
\hline \multirow{7}{*}{$\begin{array}{l}\text { Ditentukan dalam } \\
\text { kontrak }\end{array}$} & \multicolumn{4}{|c|}{ Wan prestasi antara main contractor dengan Sub contraktor } \\
\hline & \multicolumn{4}{|c|}{ Sub contraktor tidak dibayar oleh main contractor } \\
\hline & $\begin{array}{lr}\text { Sub } & \text { contractor } \\
\text { tidak } & \text { masuk } \\
\text { dalam } & \text { list } \\
\text { kontrak } & \text { antara } \\
\text { owner } & \text { dengan } \\
\text { main contractor }\end{array}$ & & & $\begin{array}{l}\text { Sub contractor } \\
\text { tidak masuk } \\
\text { dalam list } \\
\text { kontrak antara } \\
\text { owner dengan } \\
\text { main } \\
\text { contractor }\end{array}$ \\
\hline & $\begin{array}{l}\text { Tidak ada } \\
\text { perjanjian } \\
\text { subkontrak secara } \\
\text { tertulis antara } \\
\text { main contractor } \\
\text { dengan sub } \\
\text { contraktor }\end{array}$ & & & \\
\hline & $\begin{array}{l}\text { sub contractor } \\
\text { mengundurkan } \\
\text { diri }\end{array}$ & & & $\begin{array}{l}\text { sub contractor } \\
\text { mengundurkan } \\
\text { diri }\end{array}$ \\
\hline & $\begin{array}{l}\text { Pergantian sub } \\
\text { contractor }\end{array}$ & & & $\begin{array}{l}\text { Pergantian } s u b \\
\text { contractor }\end{array}$ \\
\hline & \multicolumn{4}{|c|}{$\begin{array}{l}\text { Bentuk subkontrak berbeda dengan yang ditentukan owner } \\
\text { (kontrak) }\end{array}$} \\
\hline
\end{tabular}




\begin{tabular}{|l|l|}
\hline & Owner digugat oleh sub contractor \\
\hline Tidak ditentukan & Owner digugat oleh sub contractor \\
dalam kontrak, & \\
\cline { 2 - 2 } $\begin{array}{l}\text { namun dilakukan } \\
\text { subkontrak }\end{array}$ & main contractor digugat oleh sub contractor dan sebaliknya \\
\cline { 2 - 3 } & Wan prestasi antara main contractor dengan sub contraktor \\
\cline { 2 - 3 } & Sub contraktor tidak dibayar oleh main contractor \\
\cline { 2 - 3 } & Bentuk subkontrak yang tidak diperbolehkan menurut peraturan \\
\hline
\end{tabular}

Bagan 11. permasalahan subkontrak dalam pekerjaan kontruksi

\subsection{Solusi menghadapai subkontrak dalam pekerjaan konstruksi}

Sub pembahasan solusi menghadapai subkontrak dalam pekerjaan konstruksi tidak akan mengurai lebih banyak mengenai permasalahan subkontrak sebagaimana dalam pembahasan angka 4.3. sebelumnya, karena begitu variatifnya masalah subkontrak. Setidaknya ada 4 hal yang perlu diperhatikan berkaitan menghadapai subkontrak dalam pekerjaan konstruksi, yaitu:

1. Penentuan subkontrak

Sejak awal di tahap perencanaan sudah ditentukan pekerjaan konstruksi yang dapat disubkontrak. Di dalam spesifikasi teknis dari konsultan perencana tentunya menyinggung pekerjaan/bagian yang disubkontrak. Di dalam dokumen pemilihan pun ditetapkan bentuk subkontrak yang diperbolehkan.

2. Rancangan kontrak

Ketentuan subkontrak dalam rancangan kontrak perlu didetailkan, bentuk sub kontrak yang seperti apa yang diperbolehkan, harus ijin PPK, ataupun tidak diperbolehkan. Ketentuan pemberian sanksi mengenai pelanggaran terhadap klausul subkontrak perlu dijelaskan. Larangan sub kontraktor dilarang mengalihkan atau mensubkontrakkan pekerjaan kepada subkontraktor lainnya

3. Ketentuan subkontrak

Ketentuan subkontrak pada prinsipnya mengacu pada kontrak yang berlandaskan asas-asas berkontrak. Prinsip atau asas "kekuatan mengikat persetujuan" menegaskan bahwa para pihak harus memenuhi apa yang telah diperjanjikan sehingga merupakan ikatan para pihak satu sama lain. Pasal 1338 ayat (1) KUH 
Perdata dijelaskan bahwa "semua persetujuan yang dibuat secara sah berlaku sebagai undang-undang bagi mereka yang membuatnya."

Bagan 12 berikut contoh skema kontrak yang biasa diterapkan dalam pekerjaan konstruksi pemerintah :

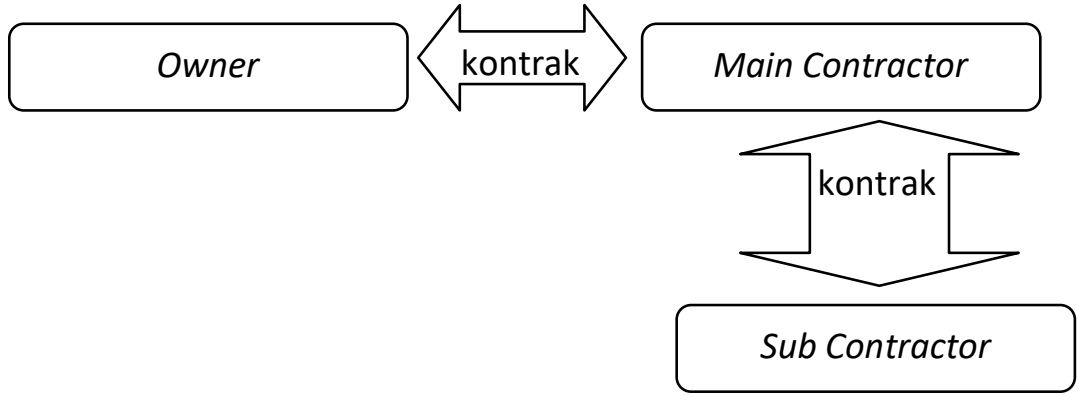

Bagan 12. Contoh skema kontrak yang biasa diterapkan dalam pekerjaan konstruksi pemerintah

Selanjutnya di dalam Pasal 1339 KUH Perdata dimasukkan prinsip kekuatan mengikat ini "suatu perjanjian tidak hanya mengikat untuk hal-hal yang dengan tegas dinyatakan didalamnya, tetapi juga untuk segala sesuatu yang menurut sifat perjanjian, diharuskan oleh kepatutan, kebiasaan atau undang-undang.” Prinsip atau asas kebebasan berkontrak yakni di mana para pihak diperkenankan membuat suatu persetujuan sesuai dengan pilihan bebas masing-masing dan setiap orang mempunyai kebebasan untuk membuat kontrak dengan siapa saja yang dikehendakinya, selain itu para pihak dapat menentukan sendiri isi maupun persyaratan-persyaratan suatu persetujuan dengan pembatasan bahwa persetujuan tersebut tidak boleh bertentangan dengan sebuah ketentuan undang-undang yang bersifat memaksa, kesusilaan, dan ketertiban umum. ${ }^{14}$ Dalam hal ini ketentuan mengenai pekerjaan konstruksi adalah undang-undang yang mengatur konstruksi maupun peraturan yang mengatur proses pengadaannya.

4.5 Mitigasi kerugian negara dalam praktik subkontrak

Melihat skema hubungan hukum subkontrak yang seperti apa tentunya melihat dari isi rancangan/kontrak itu sendiri. Hal ini agar mudah dalam memahami

${ }^{14}$ Asas-asas Hukum Pokok dalam Hukum Perjanjian, https://jdih.bssn.go.id/informasi-hukum/asasasas-hukum-pokok-dalam-hukum-perjanjian, diunduh tanggal 1 Pebruari 2019, jam 14.23. 
mengenai permasalahan yang timbul dari sengketa subkontrak. Apakah owner memiliki hubungan hukum dengan sub contractor ? Ada dua opsi jawaban yaitu ya atau tidak.

Jika tidak, istilahnya $i$ don't care. ${ }^{15}$ Owner hanya memiliki kepentingan dan hubungan hukum dengan main contractor. Segala tuntutan dari subcontractor bisa diabaikan oleh owner. Pembayaran kepada main contractor tetap sesuai kontrak. $^{16}$

Sebagai contoh, mensikapi adanya subkontrak oleh main contractor di mana tidak ada ketentuan dalam kontrak maka:

a. Jika ada laporan subkon mengenai masalah atau sebenarnya tidak boleh di subkon, owner dapat menahan pembayaran sepanjang ada klausul dalam klausul kontrak.

b. Jika sudah kebayar, maka perlu klausul kontrak yang membuka bahwa keuntungan yang sudah dibayarkan kepada main contractor dapat diminta ditarik tapi ada jangka waktu yang ditetapkan dalam kontrak.

c. Sanksi pelanggaran klausul subkontrak diberlakukan, jika ada di dalam kontrak.

Klausul menahan pembayaran maupun mengurangi keuntungan atau menarik keuntungan yang sudah dibayarkan diperlukan untuk mitigasi terhadap kerugian Negara yang timbul dari adanya pelanggaran ketentuan subkontrak. Owner tidak dianggap lalai adanya pelanggaran ketentuan subkontrak oleh main contractor, sepanjang owner telah melakukan hal-hal yang dianggap lalai atau tidak, misalnya telah patut melaksanakan ketentuan kontrak dengan pengendaliannya. Lain halnya jika terjadi tindakan pembiaran karena kurangnya pengendalian pelaksanaan kontrak atau sebenarnya mengetahui bahwa main contractor telah mensubkan pekerjaan atau suatu bentuk subkontrak kepada subcontractor, owner dianggap lalai.

15 Wawancara, Prof. Dr. FX. Joko Priyono, SH.Hum, Dosen Fakultas Hukum Undip pengampu mata kuliah Hukum Kontrak Bisnis Internasional, tanggal 1 Pebruari 2019, jam 10.00.

16 Wawancara, Prof. Dr. FX. Joko Priyono, SH.Hum, Dosen Fakultas Hukum Undip pengampu mata kuliah Hukum Kontrak Bisnis Internasional, tanggal 1 Pebruari 2019, jam 10.00. 


\section{Daftar Pustaka}

Azhar, M., Sujoko, A., \& Suharso, P. (2019). State Financial Losses Due to Corruption in Goods and Service Procurement Systems by the Government. In 2nd International Conference on Indonesian Legal Studies (ICILS 2019) (Vol. 363, pp. 232-236).

Azhar, M., \& Suhartoyo, S. (2015). Aspek Hukum Kebijakan Geothermal Di Indonesia. Law Reform, 11(1), 123-138. https://doi.org/10.14710//r.v11i1.15761

Ajik Sujoko, 2017, Outsourcing Jasa Kebersihan di Instansi Pemerintah, Majalah Masalah - Masalah Hukum, Jilid 46 No. 4, Oktober 2017.

Borvorn Israngkura Na Ayudhyaa, Masahiko Kunishimab, 2017, Risks of Abandonment in Residential Projects Caused by Subcontractors, Procedia Computer Science 121.

Hafnidar A. Rani, 2006, Manajemen Proyek Konstruksi, Yogyakarta: Deepublish.

Nurdin Syahril, Kajian Aspek Hukum Sub Kontraktor Bangunan Bawah Dan Drainase Dalam Manajemen Proyek ( Studi kasus pada rencana jembatan Layang Simpang Charitas ), Jurnal Rekayasa Sriwijaya, No. 2 Vol 19, 2010. hlm. 4.

PT. PP (Persero)-General Contractor, 2003, Buku Referensi untuk Kontraktor Bangunan Gedung dan Sipil, Jakarta: PT. Gramedia Pustaka Utama.

Pia Oedewaldn, Nadezhda Gotcheva, 2015, Safety Culture And Subcontractor Network Governance In A Complex Safety Critical Project, journal homepage: www.elsevier.com/locate/ress.

Persyaratan Kontrak Untuk Pelaksanaan Konstruksi MDB HARMONISED EDITION, yang diterjemahkan ke dalam Bahasa (dengan lisensi dari FIDIC, 10 November 2007) Indonesia oleh Sarwono Hardjomuljadi dkk.

KUH Perdata

Undang-Undang Nomor 2 Tahun 2017 tentang Jasa Konstruksi

Peraturan Presiden nomor 16 tahun 2018 tentang Pengadaan Barang/Jasa Pemerintah

Peraturan Lembaga Kebijakan Pengadaan Barang/Jasa Pemerintah Nomor 10 Tahun 2018 Tentang Pedoman Pelaksanaan Tender/Seleksi Internasional

Permen PUPR No.07/PRT/M/2019, tentang Standar dan Pedoman Pengadaan Jasa Konstruksi Melalui Penyedia

Peraturan Menteri Pekerjaan Umum dan Perumahan Rakyat Nomor: 31/PRT/M/2015 tentang Perubahan Ketiga Peraturan Menteri Pekerjaan Umum Nomor 07/PRT/M/2011 tentang Standar Dan Pedoman Pengadaan Pekerjaan Konstruksi dan Jasa Konsultansi

Pengertian Subkontraktor Pada Proyek, https://projectmedias. blogspot.com/2014/01/pengertian-subkontraktor-pada-proyek.html, diunduh tanggal 29 Januari 2019, jam 15.09. 
https://www.pikiran-rakyat.com/bandung-raya/2018/07/10/pembayaran-belumselesai-subkontraktor-demo-di-gerbang-tol-soroja-427149, di unduh tanggal 28 Januari 2019, jam 11.04

Subkontraktor, https://id.wiktionary.org/wiki/subkontraktor, diunduh tanggal 29 Januari 2019, jam 15.08.

Asas-asas Hukum Pokok dalam Hukum Perjanjian, https://jdih.bssn.go.id/informasi-hukum/asas-asas-hukum-pokok-dalamhukum-perjanjian, diunduh tanggal 1 Pebruari 2019, jam 14.23.

Wawancara, Prof. Dr. FX. Joko Priyono, SH.Hum, Dosen Fakultas Hukum Undip, pengampu mata kuliah Hukum Kontrak Bisnis Internasional, tanggal 1 Pebruari 2019, jam 10.00. 